\title{
Severe combined immunodeficiency
}

INSERM

\section{Source}

INSERM. (1999). Orphanet: an online rare disease and orphan drug data base. Severe combined immunodeficiency. ORPHA:183660

Severe combined immunodeficiency (SCID) comprises a group of rare monogenic primary immunodeficiency disorders characterized by a lack of functional peripheral $T$ lymphocytes resulting in early-onset severe respiratory infections and failure to thrive. They are classified according to immunological phenotype into SCID with absence of T cells but presence of B cells (T-B+ SCID) or SCID with absence of both (T-B-SCID) (see these terms). Both of these groups include several forms, with or without natural killer (NK) cells. 